Original Research

\title{
Removal of Arsenic from Groundwater Using Lamdong Laterite as a Natural Adsorbent
}

\author{
Phuong Thi Thanh Nguyen ${ }^{1}$, Sanou Yacouba ${ }^{2}$, Samuel Pare ${ }^{2}$, Ha Manh Bui ${ }^{3,4 *}$ \\ ${ }^{1}$ Institute for Environment and Resources, Vietnam National University, Ho Chi Minh City, Vietnam \\ ${ }^{2}$ Laboratory of Analytical Chemistry, Environmental and Bio-Organic, University of Ouagadougou, Burkina Faso \\ ${ }^{3}$ Department of Environmental Sciences, Saigon University, Ho Chi Minh City, Vietnam \\ ${ }^{4}$ NTT Institute of High Technology, Nguyen Tat Thanh University, Ho Chi Minh City, Vietnam
}

Received: 22 November 2018

Accepted: 19 January 2019

\begin{abstract}
The current study investigated the efficiency of Lamdong laterite soil using a leaching fixed-bed column, as an effective natural adsorbent for the removal of arsenic from Vietnamese groundwater. The performance of laterite was compared to that of granular ferric hydroxide (GFH), a commercial adsorbent used in arsenic removal. The effect of the parameters on this process under various operating conditions was investigated, and the experimental data were modeled using the bed depth service time (BDST) approach. According to the speciation studies, the groundwater contained $49.94 \%$ of particulate arsenic and $50.06 \%$ of soluble arsenic. The $\mathrm{As}(\mathrm{III})$ and $\mathrm{As}(\mathrm{V})$ presented at $8.4 \%$ and $91.6 \%$, respectively, in the dissolved arsenic. The analysis of the $\mathrm{pH}$ value and initial arsenic concentration showed that laterite removed more than $95 \%$ of the total arsenic from the groundwater and that the GFH material removed $99 \%$ of the arsenic at $\mathrm{pH} 3$ and $0.47 \mathrm{mg} \mathrm{As} / \mathrm{L}$. Using a molar sodium hydroxide solution, laterite was more regenable than GFH under the same experimental conditions. This suggests that natural laterite can be used as an efficient and low-cost material to reduce arsenic contamination in groundwater used for drinking.
\end{abstract}

Keywords: arsenic contamination, laterite, groundwater, adsorption

\section{Introduction}

Arsenic contamination in groundwater has become a major environmental concern in Vietnam [1] and some parts of the world [2]. The toxicity of arsenic in groundwater has been reported mostly as two inorganic forms: As (III)-arsenite and As (V) - arsenate, such as o-arsenous acids $\left(\mathrm{H}_{3} \mathrm{AsO}_{3}, \mathrm{As}_{4} \mathrm{O}_{6}, \mathrm{As}(\mathrm{OH})_{3}\right)$, m-arsenite

*e-mail: manhhakg@sgu.edu.vn ion $\left(\mathrm{AsO}_{2}^{-}, \mathrm{AsO}_{3}^{3-}, \mathrm{AsO}_{4}^{3-}\right)$, hydrolysis arsenous acids $\left(\mathrm{As}_{4} \mathrm{O}_{6}\right)$, hydrides arsenic $\left(\mathrm{As}_{2} \mathrm{H}_{4}, \mathrm{As}_{2} \mathrm{H}_{2}, \mathrm{AsH}, \mathrm{As}_{4} \mathrm{H}_{2}\right)$ or organoarsenic $\left(\mathrm{C}_{6} \mathrm{H}_{7} \mathrm{As}, \mathrm{C}_{6} \mathrm{H}_{5} \mathrm{AsCl}_{4}, \mathrm{C}_{6} \mathrm{H}_{5} \mathrm{AsCl}_{2}\right)$, depending on the types of sediment or minerals in the water source areas or the $\mathrm{pH}$ value of the water [3]. While As (V) species are less toxic and strongly adsorbed to different types of mineral surfaces, especially iron hydroxides/oxides [4], As (III) species are not only more toxic than arsenate but also more difficult to eliminate from water [5].

Both arsenic forms had been detected in Vietnam.Winkel et al. [6] has stated that the arsenic 
Table 1. Elemental composition and typical physical properties of natural laterite soil [16].

\begin{tabular}{|c|c|c|c|c|c|c|c|c|c|}
\hline $\begin{array}{c}\text { Elemental } \\
\text { compositions } \\
\%(\mathrm{w} / \mathrm{w})\end{array}$ & $\mathrm{Si}$ & $\mathrm{Al}$ & $\mathrm{Fe}$ & $\mathrm{Mg}$ & $\mathrm{Ca}$ & $\mathrm{Ti}$ & $\mathrm{Na}$ & $\mathrm{C}$ & $\mathrm{O}$ \\
\cline { 2 - 10 } & 34.27 & 19.87 & 7.79 & 5.06 & 4.59 & 1.68 & 1.31 & 4.4 & 19.87 \\
\hline $\begin{array}{c}\text { Physical } \\
\text { properties } \\
\text { Values }\end{array}$ & $\mathrm{pH}$ & \multicolumn{2}{|c|}{$\mathrm{BET}$ surface $\left(\mathrm{m}^{2} / \mathrm{g}\right)$} & $\begin{array}{c}\text { Pore diameter } \\
(\mathrm{nm})\end{array}$ & $\begin{array}{c}\text { Grain size } \\
(\mathrm{mm})\end{array}$ & $\begin{array}{c}\text { Bulk density } \\
(\mathrm{g} / \mathrm{mL})\end{array}$ & $\begin{array}{c}\text { Moisture content } \\
(\%)\end{array}$ & $\begin{array}{c}\text { Porosity } \\
(\%)\end{array}$ \\
\cline { 2 - 10 } & 6.69 & \multicolumn{2}{|c|}{10.96} & 2.32 & $0.45-2$ & 1.91 & 0.43 & $97-99$ \\
\hline
\end{tabular}

contamination in the groundwater from the Mekong Delta in Vietnam is naturally occurring and is caused by the chemical- and microbial-induced reductive dissolution of iron-oxides in the alluvial sediments in the delta. They also suggested that arsenic is released from the delta sediments because of the reductive dissolution of the iron-bearing minerals and that arsenic concentrations in the region can reach $1300 \mu \mathrm{g} / \mathrm{L}$. According to Luu [1], the arsenic concentration in the groundwater in Dongthap, a Mekong Delta province in the south of Vietnam, has ranged from 0.1 to $1352 \mu \mathrm{g} / \mathrm{L}$. The consumption of these arsenic-enriched waters has caused health issues, including skin rashes, breathing problems, general tiredness and chronic diarrhoea, related to the groundwaters of this region.

Arsenic pollution has also affected people in most of the north of Burkina Faso in Africa. Issues such as melanosis, hyperkeratosis and skin changes have been attributed to the arsenopyrite species in the bedrock [7]. The arsenic concentration in this area increases when the depth of the wells increases.

Various technologies have been developed for arsenic treatment. Major technologies include precipitation-coagulation, membrane separation, ion exchange, advanced oxidation and adsorption [8]. Among them, adsorption is one of the most popular processes for arsenic removal from water because of its cost-effective, high affinity of dissolved arsenic and can also be used in small-scale household units [9]. Moreover, many reports have indicated that cheap natural adsorbents such as zeolites, ferric hydroxide, laterite, etc. could successfully eliminate arsenic from water $[10,11]$.

In Vietnam, late rite soil is distributed mainly in coastal areas, particularly Lamdong Province, and is normally abandoned land due to poor fertility. However, as compared with other laterites in Africa or other parts of Asia, Lamdong laterite - a "soft-doughy" material has some special characteristics and can be used as a special building material [12]. In an effort to utilise this waste soil, Pham et al. [13] presented a method to modify northern Vietnam laterite as an alternative absorbent for successfully removing $\mathrm{Cu}^{2+}$ in simulated wastewater $(91 \%)$. To the best of our knowledge, no publication has investigated the efficiency of this Lamdong laterite on water treatment. Moreover, a number of arsenic removal studies have been conducted by batch experiments, and only a few works on column studies have been reported $[11,14]$.
The basic objective of this study was then (i) to investigate sorption efficiency of natural laterite soil and commercial GFH material on the As removal from groundwater among three factors $(\mathrm{pH}$, initial arsenic concentrations, and hydrological regimes in the column on breakthrough curves) and (ii) to model the dynamics of adsorption process using the bed depth service time (BDST) approach.

\section{Experimental}

\section{Materials}

Natural laterite soil was collected in a highland area of Lamdong Province, Vietnam. This laterite soil, which has a reddish brown colour, was washed with distilled water. It was then crushed and dried at $105^{\circ} \mathrm{C}$ for $24 \mathrm{~h}$ before being used as described by Maji et al. [15]. The elemental composition and typical physical properties of laterite were studied by Sanou et al. [16] and are presented in Table 1.

Granular ferric hydroxide (GFH) was purchased from Wasserchemie GmbH (GEH), Germany. Its physical properties are presented in Table 2.

Groundwater was collected in Dongthap Province in October 2015. The samples were then shipped to the Institute for Environment and Resources (IER) laboratory on the same day and stored at $4^{\circ} \mathrm{C}$ before use. Total As, soluble As and As(III) were determined using a hydride generation-atomic absorption spectrophotometer (HG-AAS). After filtering, the soluble As was acidified to $\mathrm{pH} 3$ before analysis. The particulate As was obtained by deducting the soluble As from the total As. The content of the $\mathrm{As}(\mathrm{V})$ was obtained by deducting the As(III) content from the soluble As. Parameters such as

Table 2. Physical properties of GFH materials.

\begin{tabular}{|c|c|}
\hline Physical properties & Values \\
\hline $\mathrm{pH}_{\mathrm{ZPC}}$ & $7.6-7.8$ \\
\hline BET surface $\left(\mathrm{m}^{2} / \mathrm{g}\right)$ & $240-300$ \\
\hline Grain size $(\mathrm{mm})$ & $0.32-2$ \\
\hline Bulk density $(\mathrm{g} / \mathrm{mL})$ & 1.19 \\
\hline Moisture content $(\%)$ & $43-48$ \\
\hline Porosity $(\%)$ & $72-77$ \\
\hline
\end{tabular}


temperature, $\mathrm{pH}$ values, and conductivity were measured using the $\mathrm{pH}$ meter Inolab serial WTW 730 and the Handy Lab 2000. Other parameters, e.g., chemical oxygen demand (COD), biochemical oxygen demand for five days $\left(\mathrm{BOD}_{5}\right)$ and total dissolved solids (TDS) were determined using the standard methods as described elsewhere [17]. All measurements were repeated three times to verify the result. The average values are given in Table 3.

All chemicals used were analytical grade. Distilled water was used to lower the arsenic concentration during the experiments, and $\mathrm{As}(\mathrm{V})$ standard solution $\mathrm{H}_{3} \mathrm{AsO}_{4} 1,000 \mathrm{mg} / \mathrm{L}$ was used to increase the arsenic concentration during analysis of the initial arsenic concentration. The concentration of arsenic in the effluent water was higher than $1 \mu \mathrm{g} / \mathrm{L}$ (the detection limit that can be achieved by the analytical methods used in this study).

Table 3. Physical-chemical properties of the groundwater sample.

\begin{tabular}{|c|c|}
\hline Parameter* & Average values \\
\hline $\mathrm{pH}$ & 6.91 \\
\hline Temperature $\left({ }^{\circ} \mathrm{C}\right)$ & 20.1 \\
\hline $\mathrm{EC}(\mu \mathrm{S} / \mathrm{cm})$ & 334 \\
\hline total dissolved solids $(\mathrm{mg} / \mathrm{L})$ & 180.6 \\
\hline Total suspended solids (mg/L) & 35 \\
\hline Total solid (mg/L) & 227.2 \\
\hline Total Hardness (mg/L) & 198 \\
\hline Total Alkalinity (mg/L) & 99 \\
\hline Total iron $(\mathrm{mg} / \mathrm{L})$ & 11.24 \\
\hline $\mathrm{COD}(\mathrm{mg} / \mathrm{L})$ & 65.5 \\
\hline $\mathrm{BOD}_{5}(\mathrm{mg} / \mathrm{L})$ & 10 \\
\hline $\mathrm{DO}(\mathrm{mg} / \mathrm{L})$ & 5.27 \\
\hline Ammonia (mg/L) & 26 \\
\hline Fluoride $(\mathrm{mg} / \mathrm{L})$ & 0.42 \\
\hline Chloride $(\mathrm{mg} / \mathrm{L})$ & 25 \\
\hline Sulfate $(\mathrm{mg} / \mathrm{L})$ & 9.6 \\
\hline Bicarbonate $(\mathrm{mg} / \mathrm{L})$ & 390 \\
\hline Phosphate (mg/L) & 1.34 \\
\hline Total As (mg/L) & 0.472 \\
\hline Particulate As (mg/L) & 0.236 \\
\hline Soluble As (mg/L) & 0.236 \\
\hline As (III) (mg/L) & 0.020 \\
\hline As $(\mathrm{V})(\mathrm{mg} / \mathrm{L})$ & 0.216 \\
\hline
\end{tabular}

*EC: Electrical conductivity, COD: Chemical oxygen demand, $\mathrm{BOD}_{5}$ : Biochemical oxygen demand for 5 days, DO: Dissolved oxygen.

DO: Dissolved oxygen

\section{Arsenic Speciation Experiments}

The experiment was conducted using the protocol described by Thirunavukkarasu et al. [18].

\section{Leaching Fixed-Bed Column Experiments}

A leaching fixed-bed column system was set up to study the efficiency of the removal of As from groundwater using both laterite and GFH. The column was designed with an internal diameter of $28 \mathrm{~mm}$ and a length of $225 \mathrm{~mm}$. At first, the materials were packed in different columns at different bed depths. Doubledistilled water was used to wash the materials 5 times before use. Arsenic-enriched groundwater was loaded on the top of the column. The effluent water was collected at the bottom, and the remaining $\mathrm{As}(\mathrm{V})$ concentration was analyzed. The bottom of the column was secured using glass wool and glass beads.

Fixed-bed column experiments were conducted under various conditions to evaluate the influence of initial $\mathrm{pH}$ values, initial As concentrations and column hydrological regimes on the efficiency of As removal. The percentage of arsenic removal was calculated as follows:

$$
\text { As removal efficieny }=\frac{C_{0}-C_{e}}{C_{0}} \times 100
$$

...where $\mathrm{C}_{0}$ and $\mathrm{Ce}$ represent the concentration of arsenic in influent water and effluent water $(\mu \mathrm{g} / \mathrm{L})$, respectively.

\section{Effect of $\mathrm{pH}$ Values}

The columns were first packed with $15 \mathrm{~g}$ of laterite, and the flow rate was fixed at $8.8 \mathrm{~mL} / \mathrm{min}$ using natural groundwater with a real-life initial arsenic concentration of $0.47 \mathrm{mg} / \mathrm{L}$. The $\mathrm{pH}$ values were fixed at 3, 5, 7, 9 and 11 . They were then adjusted with stock solutions $1.0 \mathrm{M} \mathrm{NaOH}$ or $1.0 \mathrm{M} \mathrm{HNO}_{3}$. After loading these solutions into the columns, the effluent water was collected at the bottom to determine total residual arsenic.

A similar system packed with the GFH material was set up to compare the efficiency of As removal for the two adsorbents.

\section{Effect of Initial Arsenic Concentrations}

In this study, the columns were also packed with laterite $15 \mathrm{~g}$ - the equivalent of a $2.2 \mathrm{~cm}$ bed depth). Groundwater was prepared with various initial concentrations of $0.33,0.47,2.42,6.33$ and $10.24 \mathrm{mg} / \mathrm{L}$ of the total As by adding a specific volume of $\mathrm{As}(\mathrm{V})$ stock solution - 1,000 $\mathrm{mg} / \mathrm{L}$. These solutions were also adjusted to $\mathrm{pH} 3$ and were loaded at the top of the columns. The concentrations of total As were determined in the collected effluent water. 


\section{Effect of Operational Column Regimes}

Arsenic-enriched groundwater with an initial As(V) concentration of $0.47 \mathrm{mg} / \mathrm{L}$ was loaded in the column with arsenic-spiked groundwater in the up-flow mode with a volumetric flow rate of $11.4 \mathrm{~mL} / \mathrm{min}$ for $\mathrm{GFH}$ and $9.7 \mathrm{~mL} / \mathrm{min}$ for laterite. The initial concentration of arsenic in the groundwater sample was $0.47 \mathrm{mg} / \mathrm{L}$.

Fixed-bed column experiments were conducted using the column packed with the GFH material at 1 , 1.8 and $2.5 \mathrm{~cm}$ depths; then they were conducted with the laterite soil at depths such as $0.9,1.6$ and $2.2 \mathrm{~cm}$. The amounts of both materials used were $5 \mathrm{~g}, 10 \mathrm{~g}$, and $15 \mathrm{~g}$, respectively, for the columns of the bed depths above. Two values for the flow rates and initial arsenic concentrations were used to evaluate the effects of both parameters on the breakthrough curves and the service times of the columns.

\section{Analysis and Modeling of Column Data}

The modeling of the adsorption column design parameters was based on the bed depth/service time approach. The design of full-scale adsorption columns can be accomplished by using the data collected during the laboratory and pilot plant tests.

Several mathematical models have been developed for use in the design of full-scale adsorption columns. The model proposed by Bohart et al. [19] is widely used $[8,13,20,21]$. This approach is focused on the estimation of characteristic parameters such as $N_{0}$, maximum adsorption capacity; $K$, adsorption rate constant; and $x$, critical bed depth. The simplified equation of Bohart and Adams [19], based on surface reaction rate theory and the service time, is presented as follows:

$$
t=\frac{N_{0}}{C_{0} V} x-\frac{1}{C_{0} K} \ln \left(\frac{C_{0}}{C_{B}}-1\right)
$$

...where $C_{0}=$ the initial solute concentration $(\mathrm{mg} / \mathrm{L})$; $C_{\mathrm{B}}=$ the desired solute concentration at breakthrough $(\mathrm{mg} / \mathrm{L}) ; K=$ the adsorption rate constant $(\mathrm{L} / \mathrm{mg} . \mathrm{h})$; $N_{0}=$ the adsorption capacity $(\mathrm{mg} / \mathrm{L}) ; x=$ the bed depth $(\mathrm{cm}) ; V=$ the linear flow velocity of feed to bed $\left(\mathrm{m}^{3} / \mathrm{h}\right.$. $\mathrm{m}^{2}$ ); and $t=$ the service time of the column under the above conditions (h).

The form of the Bohart-Adams equation, shown in Eq. (2), can be used to determine the service time $(t)$ of a column of bed depth $(x)$, given the values of $N_{0}, C_{0}$ and $K$, which must be determined for laboratory columns operated over a range of velocity values $V$. Setting $t=0$, and solving Eq. (2) for $x$ yields

$$
x_{0}=\frac{V}{K N_{0}} \ln \left(\frac{C_{0}}{C_{B}}-1\right)
$$

...where $x_{0}$ is the minimum column height necessary to produce an effluent concentration $C_{\mathrm{B}}$.
Hutchins [22] presented a modification of the BohartAdams equation that seeks to collect only the necessary data from the three column tests. In this technique, the BDST approach, the Bohart-Adams equation is expressed as follows:

$$
t=a x+b
$$

...where

$$
\begin{gathered}
a=\text { slope }=\frac{N_{0}}{C_{0} V} \\
b=\text { intercept }=\frac{1}{K C_{0}} \ln \left(\frac{C_{0}}{C_{B}}-1\right)
\end{gathered}
$$

\section{Results and Discussion}

\section{Arsenic Speciation}

Raw laterite soil was used to prepare a resin in the acetate form according to the method described by Thirunavukkarasu and Viraraghavan [18]. The resin was used as an adsorbent in the column (fixed bed) to remove the $\mathrm{As}(\mathrm{V})$ in the dissolved arsenic by an anion exchange process. The calculations showed that the groundwater contained $49.94 \%$ of particulate arsenic and $50.06 \%$ of soluble arsenic. In the soluble arsenic, $\mathrm{As}(\mathrm{III})$ represented $8.40 \%$, and $\mathrm{As}(\mathrm{V})$ was $91.6 \%$. These results showed that the groundwater contained more $\mathrm{As}(\mathrm{V})$, which is more easily removable than $\mathrm{As}(\mathrm{III})$. The presence of $\mathrm{As}(\mathrm{III}), \mathrm{As}(\mathrm{V})$ and the particulate form in the groundwater sample with a predominance of $\mathrm{As}(\mathrm{V})$ is in agreement with the results of previous studies $[10,23]$.

\section{Effect of Initial $\mathrm{pH}$ on the Percentage of Arsenic Removal}

$\mathrm{pH}$ value is an important parameter that has a considerable effect on the efficiency of As removal and on arsenic species in column experiments. As described in Fig. 1, the optimum percentages for arsenic removal were $98 \%$ and $93 \%$ at $\mathrm{pH}=3$ using $\mathrm{GFH}$ and laterite, respectively, and at the same $\mathrm{pH}$ value the percentage of removed arsenic using GFH is slightly higher than that found with laterite. This indicates a higher capacity of GFH in arsenic removal because of its high surface area (see Tables 1 and 2). However, these percentages indicate the use of laterite as an alternative adsorbent for the treatment of arsenic-enriched water. High percentages of arsenic removal resulted from the strong contribution of $\mathrm{As}(\mathrm{V})$ in soluble As (see Table 3). The figure also shows that the As removal percentage significantly decreased from 96 to $70 \%$ as $\mathrm{pH}$ decreased from 7 to 9 and decreased from 91 to $67 \%$ as $\mathrm{pH}$ decreased from 5 to 9 when using GFH and laterite, respectively. These results can be attributed to the decrease in electrostatic 


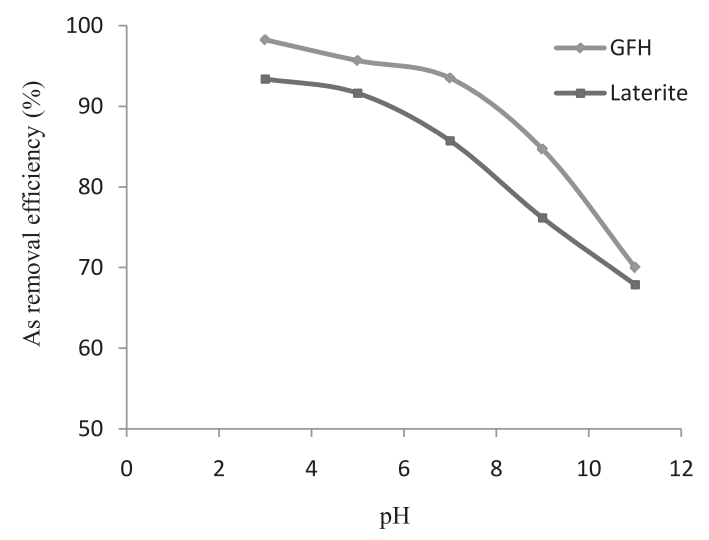

Fig. 1. Effect of initial $\mathrm{pH}$ on arsenic removal using $\mathrm{GFH}$ and Laterite with $\mathrm{m}=15 \mathrm{~g}, \mathrm{C}_{0}=0.47 \mathrm{mg} / \mathrm{L}$, and flow rate $=8.8 \mathrm{~mL} / \mathrm{min}$.

interactions between the charged surface of the adsorbents and multipotent anionic multipotent anionic of $\mathrm{As}(\mathrm{V})$ species such as $\mathrm{HAsO}_{4}^{2-}$ and $\mathrm{H}_{2} \mathrm{AsO}_{4}^{-}$[24]. At $\mathrm{pH}$ value higher than $\mathrm{pH}_{\mathrm{zpc}}$ of laterite and GFH (see Table 1 and 2), the hydroxyl groups on the materials were deprotonated to a negative charge that wouldreact inefficiently with the anions species of $\operatorname{As}(\mathrm{V})$ and therefore reduce arsenic removal efficiency. On the contrary, at $\mathrm{pH}$ value lower than $\mathrm{pH}_{\mathrm{zpc}}$ of these materials, the positively charged surface of laterite and GFH could efficiently interact with the anions species of $\mathrm{As}(\mathrm{V})$ and enhance removal efficiency [25]. According to Sanou and Pare [16], physisorption could be the mechanism for arsenic adsorption on GFH, and laterite might involve Van Der Waals bonds through a multilayer process.

\section{Effect of Initial Arsenic Concentration on Arsenic \\ Removal Percentage and Breakthrough Curves}

In order to study the adsorption performance of both materials (GFH and laterite) at different arsenic concentrations, the column was run with initial arsenic concentrations of 0.237 and $1.45 \mathrm{mg} / \mathrm{L}$, respectively. By using GFH, the bed depth and column diameters were 2.5 and $3 \mathrm{~cm}$, respectively.

When the initial As concentrations were increased from 0.33 to $10.23 \mathrm{mg} / \mathrm{L}$, the percentage of As removal using the GFH and the laterite increased from 95 to $99.8 \%$ and from 64 to $97.5 \%$, respectively (see Fig. 2). This increase in arsenic removal can be explained as the result of the occupation of free sites, inaccessible at low concentrations of adsorbate [8, 9]. Moreover, higher percentages of removal were obtained by using GFH than by using laterite, which indicates the higher capacity of GFH. When the initial arsenic concentration was higher than $6 \mathrm{mg} / \mathrm{L}$, the adsorption capacity of laterite was $66.57 \mu \mathrm{g} / \mathrm{g}$, compared to that of GFH $(68.1 \mu \mathrm{g} / \mathrm{g})$. This result could be explained by the enhancement of the occupation of the active sites by phosphate, bicarbonate, and sulfate, which were present

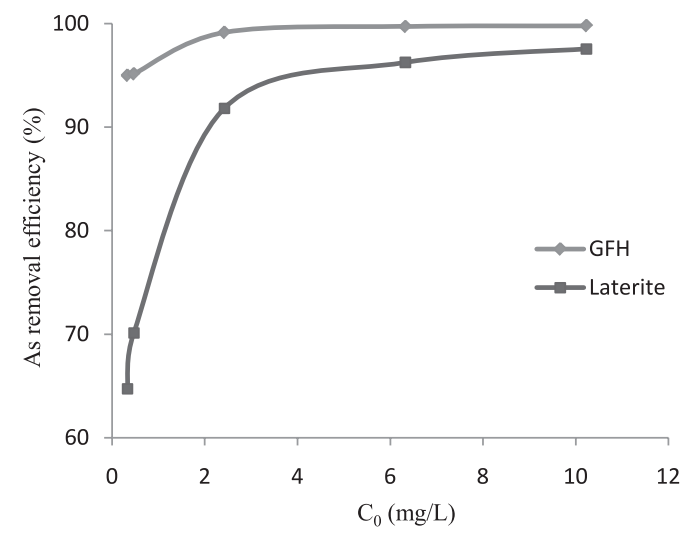

Fig. 2. Effect of influent concentration on arsenic removal using GFH and laterite with $\mathrm{m}=15 \mathrm{~g}, \mathrm{pH}=7-7.4$, flow rate $=7 \mathrm{~mL} / \mathrm{min}$.

in the natural groundwater (see Table 3). This relaxed more sites on the laterite after adsorption [26].

In order to study the effect of the initial arsenic concentrations on breakthrough curves and column service times, the column was run with initial arsenic concentrations of 0.237 and $1.45 \mathrm{mg} / \mathrm{L}$. Using
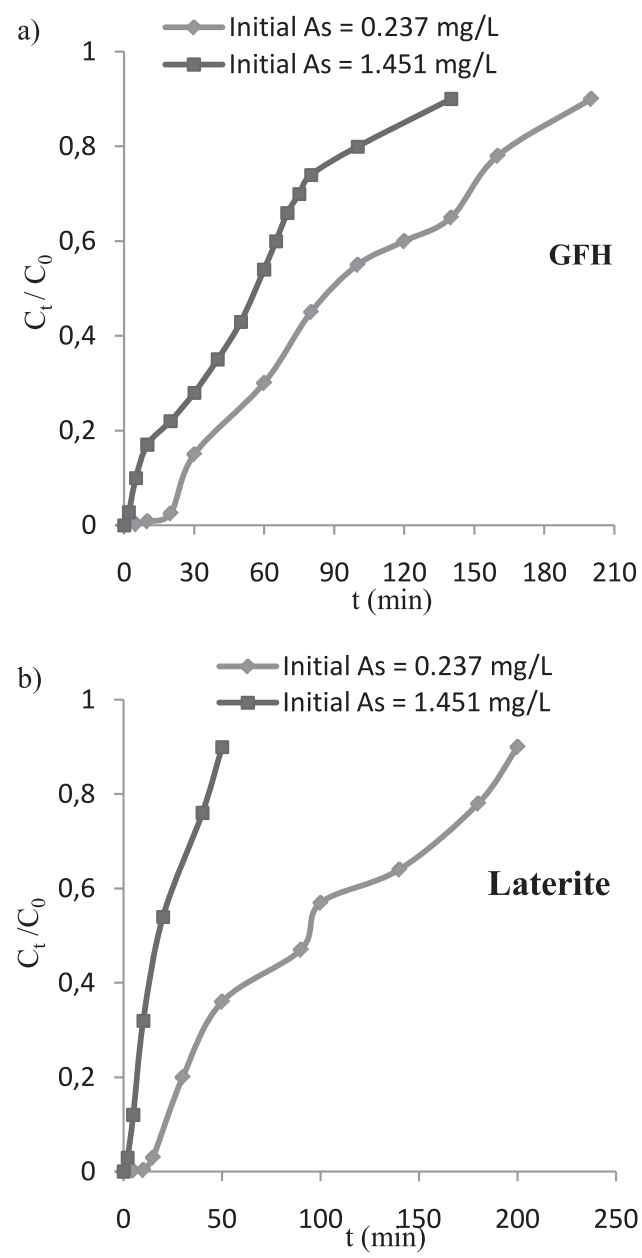

Fig. 3. Effect of initial concentration on breakthrough curves in arsenic removal using a) GFH and b) laterite. 
GFH, the bed depth and column diameter were 2.5 and $3 \mathrm{~cm}$, respectively, with the flow rate kept to $8 \mathrm{~mL} / \mathrm{min}$. The breakthrough times for influent concentrations of 0.237 and $1.45 \mathrm{mg} / \mathrm{L}$ were found to be 20 and 2 min, respectively (see Fig. 3). The exhaust times (corresponding to $90 \%$ of the influent concentration) for the influent concentrations of 0.237 and $1.45 \mathrm{mg} / \mathrm{L}$ were found to be 200 and $140 \mathrm{~min}$, respectively. The same operations were done with 2.2 com of laterite. The breakthrough occurred at 15 and $2 \mathrm{~min}$ with exhaustion for 200 and $50 \mathrm{~min}$ for influent concentrations of 0.237 and $1.45 \mathrm{mg} / \mathrm{L}$, respectively (see Fig. 3). The decrease in the column service times (breakthrough and exhaustion) at higher initial concentrations may be the result of the rapid exhaustion of the sorption sites. Besides, the saturation of the bed was faster at the higher initial arsenic concentrations [21].

\section{Effect of Flow Rate on Breakthrough Curves}

As seen in Fig. 4, the experimental breakthrough times (corresponding to $2 \%$ of influent concentration) for flow rates 5.4 and $12.2 \mathrm{~mL} / \mathrm{min}$ were found to be 20 and $5 \mathrm{~min}$, respectively. The exhaust times (corresponding to $90 \%$ of influent concentration) for flow rates 5.4 and $12.2 \mathrm{~mL} / \mathrm{min}$ were found to be 240 and $180 \mathrm{~min}$, respectively. The same operations were repeated using
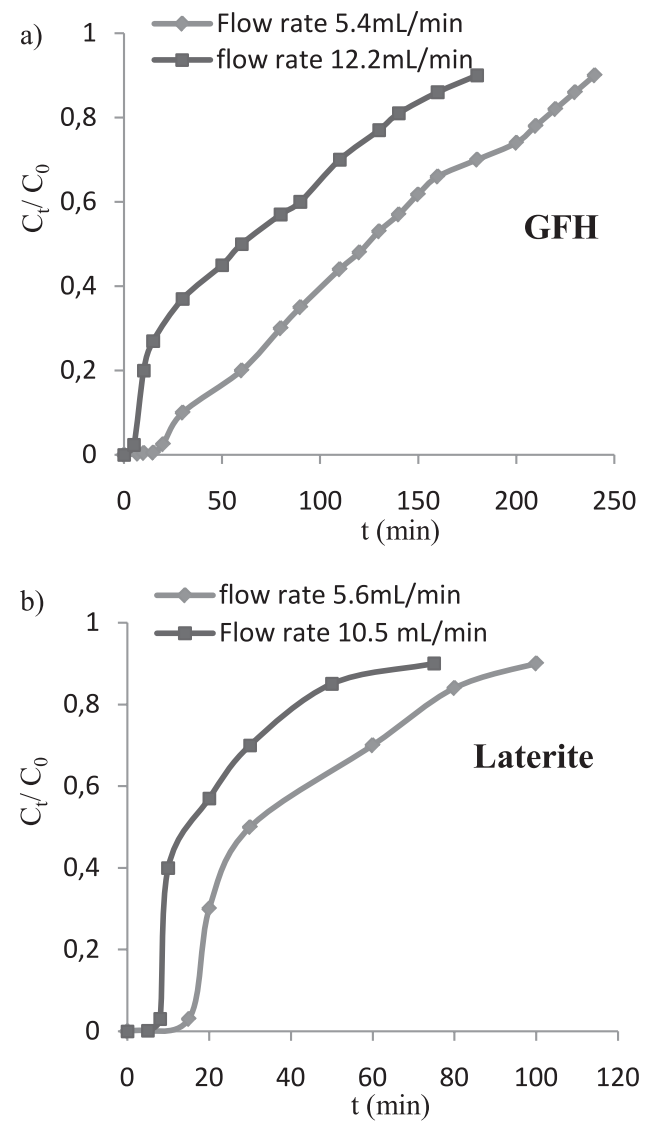

Fig. 4. Effect of flow rate on breakthrough curves in arsenic removal using a) GFH and b) laterite. laterite with the original flow rate of $9.7 \mathrm{~mL} / \mathrm{min}$ and the same initial influent concentration. The flow rates used were 5.6 and $10.5 \mathrm{~mL} / \mathrm{min}$ with bed depth and column diameter of 2.2 and $3 \mathrm{~cm}$, respectively. The experimental breakthroughs (corresponding to $3 \%$ of the influent concentration) for the flow rates of 5.6 and $10.5 \mathrm{~mL} / \mathrm{min}$ were produced at 15 and $3 \mathrm{~min}$, respectively. The exhaustion (corresponding to $90 \%$ of influent concentration) for flow rates 5.6 and $10.5 \mathrm{~mL} / \mathrm{min}$ occurred at 120 and $75 \mathrm{~min}$, respectively. The above-mentioned results indicate that an increase in the flow rate caused a decrease in the contact time, and this involved a decrease in removal efficiency [20]. With the lower flow rate, the removal efficiency increased, and the empty bed contact time (EBCT) increased.

\section{Effect of Operational Column Regimes}

The plots of effluent As concentrations, as a function of lapse time or volume of water treated are the breakthrough curves. The points on the breakthrough curves at which the As concentration reached its maximum allowable value of $0.01 \mathrm{mg} / \mathrm{L}$ (corresponding o $\mathrm{C} / \mathrm{C}_{0}=0.02$ using $\mathrm{GFH}, \mathrm{C} / \mathrm{C}_{0}=0.03$ with laterite) was taken as the 'breakthrough point', corresponding to $90 \%$ of the influent concentration as the 'point of exhaustion'.
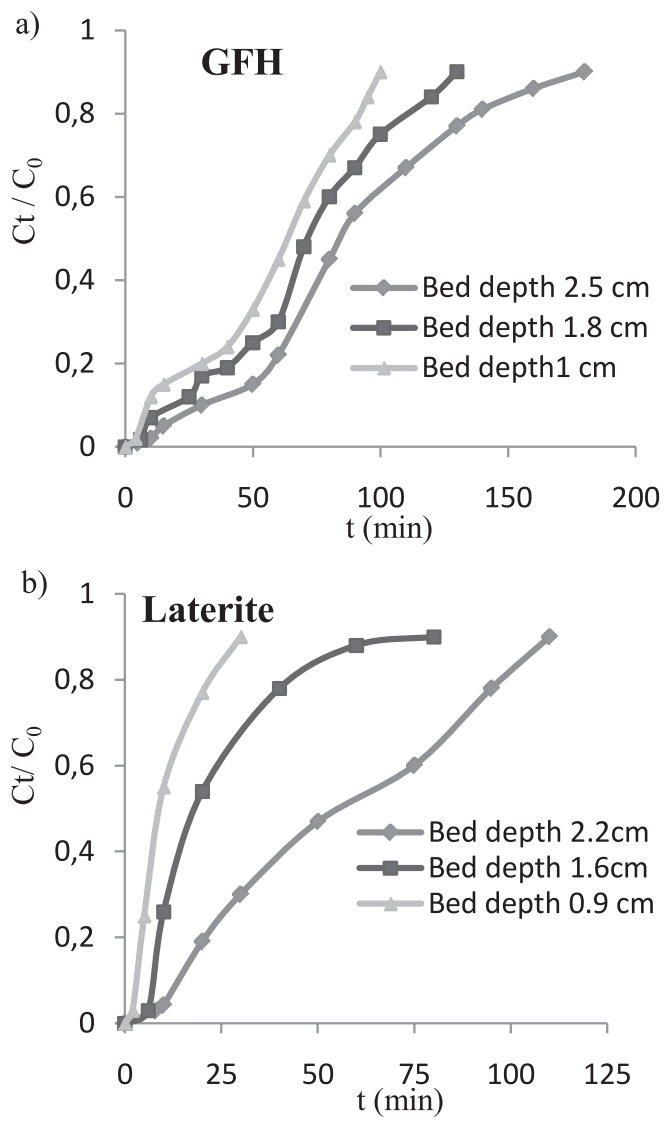

Fig. 5. The breakthrough curves of arsenic removal by a) GFH and b) laterite soil-packed columns of different bed depths (initial arsenic concentration $=0.47 \mathrm{mg} / \mathrm{L}$, flow rate $=11.4 \mathrm{~mL} / \mathrm{min}$ for $\mathrm{GFH}$ and $9.7 \mathrm{~mL} / \mathrm{min}$ for laterite). 
Table 4. Important column behavior parameters.

\begin{tabular}{|c|c|c|c|c|c|c|}
\hline \multirow{2}{*}{ Parameter } & \multicolumn{3}{|c|}{ GFH } & \multicolumn{3}{c|}{ Natural laterite } \\
\cline { 2 - 7 } & Depth $1 \mathrm{~cm}$ & Depth $1.8 \mathrm{~cm}$ & Depth $2.5 \mathrm{~cm}$ & Depth $0.9 \mathrm{~cm}$ & Depth $1.6 \mathrm{~cm}$ & Depth $2.2 \mathrm{~cm}$ \\
\hline $\mathrm{t}_{\mathrm{z}}(\mathrm{min})$ & 96 & 124 & 170 & 28 & 74 & 102 \\
\hline $\mathrm{h}_{\mathrm{z}}(\mathrm{cm})$ & 0.96 & 1.73 & 2.46 & 1.12 & 1.81 & 2.36 \\
\hline $\mathrm{U}_{\mathrm{z}}(\mathrm{cm} / \mathrm{min})$ & 0.010 & 0.014 & 0.014 & 0.040 & 0.024 & 0.023 \\
\hline Bed saturation (\%) & 94.5 & 97 & 96 & 76.35 & 77.4 & 83.9 \\
\hline
\end{tabular}

The breakthrough curves are shown in Fig. 5a) and 5 b) using GFH and laterite, respectively. The important parameters for the column behaviorare regrouped in Table 4.

Using GFH, the breakthrough times were found to be 4, 6 and 10 mins for $1,1.8$ and $2.5 \mathrm{~cm}$ bed depths, respectively, corresponding to $50 \mathrm{~mL}, 70 \mathrm{~mL}$ and $110 \mathrm{~mL}$ of bearing-treated water at the breakthrough point. The exhaustion was achieved at 100, 130 and 200 mins, respectively, corresponding to $1140 \mathrm{~mL}$, $1480 \mathrm{~mL}$ and $2050 \mathrm{~mL}$ of treated water at the exhausted times. With laterite as the fixed bed, the obtained breakthrough times were 2, 6 and 8 mins for $0.9,1.6$ and $2.2 \mathrm{~cm}$ of bed depth, respectively, corresponding to $20 \mathrm{~mL}, 60 \mathrm{~mL}$ and $80 \mathrm{~mL}$ of treated water at breakthrough. The exhaustion occurred at 30,80 and 110 mins, respectively, corresponding to $300 \mathrm{~mL}$, $800 \mathrm{~mL}$ and $1070 \mathrm{~mL}$ of treated water.

Different parameters for the columns, such as the time required for the exchange zone to move its own height $(t z)$, the height of the adsorption zone $(h z)$, the rate at which the adsorption zone moves up or down through the bed $(U z)$ and bed saturation have been calculated according to the concepts explained by Kundu and Gupta [20]. The obtained results are presented in Table 4. The removal trends correspond to the findings of Maji and Pal [15], and Maiti and Das Gupta [25]. Using the same weights for the adsorbents, the columns with GFH were more exhausted compared to those packed with laterite. The lower speed of the adsorption area (Uz) using GFH as a fixed bed could be the result of the low porosity and density of this material.

\section{Analysis and Modeling of Column Data}

The design of the full-scale adsorption columns was based on the data collected during the study of the effect of bed depth on the breakthrough curves. These data were used in the application of the BDST approach and the presentation and analysis of the results as well.

These are the breakthrough times (corresponding to $C / C_{0}=0.02$ ) and the exhaust times (corresponding to $C / C_{0}=0.9$ ) for bed depths $1,1.8$ and $2.5 \mathrm{~cm}$ using $\mathrm{GFH}$, as previously mentioned. In addition, these are the breakthrough times (corresponding to $C / C_{0}=0.03$ ) and exhaust times (corresponding to $C / C_{0}=0.9$ ) for bed depths $0.9,1.6$ and $2.2 \mathrm{~cm}$ using laterite, as previously mentioned. The graphs, as seen in Fig. 6, show the bed depths vs. the service times using GFH for 2 and $90 \%$ saturation of the columns and using laterite for 3 and $90 \%$ saturation of columns. The equations for using GFH are as follows:

$$
\begin{gathered}
t=0.8805 x+0.7245 \text { for } 90 \% \text { saturation } \\
t=0.0661 x-0.0054 \text { for } 2 \% \text { saturation }
\end{gathered}
$$

For the laterite, the following equations were used:

$$
\begin{aligned}
& t=1.0276 x-0.3898 \text { for } 90 \% \text { saturation } \\
& t=0.0776 x-0.0348 \text { for } 3 \% \text { saturation }
\end{aligned}
$$

From the slope and intercept of a $2 \%$ saturation line (Eq. (8)), the design parameters $K$ and $N_{0}$ were found using Eqs. (5) and (6). The minimum column height $\left(x_{0}\right)$ required to produce an effluent concentration of $C_{\mathrm{B}}$ was calculated using Eq. (3). The values of $K, N_{0}$, and $x_{0}$ were found to be $937 \mathrm{~L} / \mathrm{mg}$. h, $3 \mathrm{mg} / \mathrm{L}$ and $0.082 \mathrm{~cm}$, respectively.

From the slope and intercept of the 3\% saturation line (Eq. (10)) and proceeding in the same manner, the values of $K, N_{0}$, and $x_{0}$ were found to be $211 \mathrm{~L} / \mathrm{mg}$. h; $3 \mathrm{mg} / \mathrm{L}$; and $0.45 \mathrm{~cm}$, respectively. A comparison of the $\mathrm{N}_{0}$ values shows a similar volumetric capacity for GFH and laterite ( $3 \mathrm{mg} \mathrm{As} / \mathrm{L}$ of adsorbent), corresponding to a mass capacity of $0.02 \mathrm{mg} / \mathrm{g}$ for each adsorbent. Adsorption occurred in the column at minimum bed depths of $0.082 \mathrm{~cm}$ and $0.45 \mathrm{~cm}$ using GFH and laterite, respectively. These values allowed for an understanding of the capacities of GFH and laterite.

\section{Prediction of Service Times of Columns under Various Operating Conditions}

The BDST approach was used for a theoretical evaluation of the breakthrough and exhaustion times. The column design parameters obtained earlier were used for the design of practical applications for an adsorption column. According to the BDST approach, if the $a$ value is determined for one flow rate, the values for the other flow rates can be calculated by multiplying the original slope by the ratio of the original and the new flow rates. It is not necessary to adjust the $b$ value 

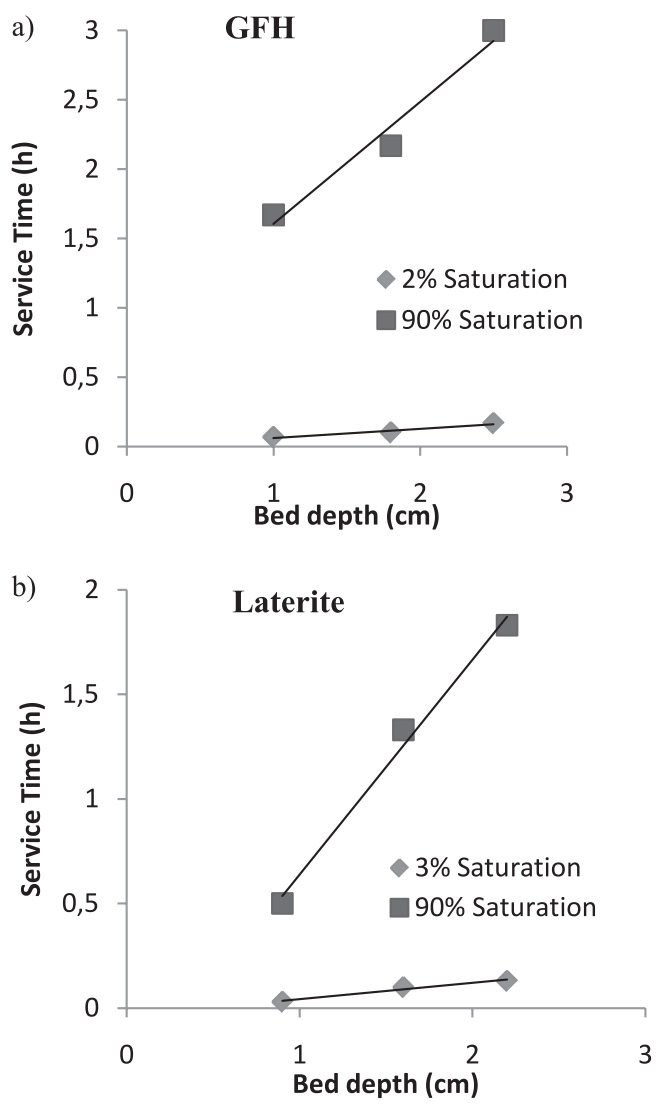

Fig. 6. Bed depth service time (BDST) curve of arsenic removal at breakthrough and exhaustion times using a) GFH and b) laterite.

because this term is assumed to be insignificantly affected by changing flow rates. But the values of $a$ were calculated separately regarding the breakthrough and exhaustion times. Using GFH, the revised values of $a$, calculated from the flow rate ratio for the breakthrough times, were 0.1395 and 0.6176 , while for the exhaustion times the calculated values of $a$ were 1.8588 and 0.8227 for flow rates of 5.4 and $12.2 \mathrm{~mL} / \mathrm{min}$, respectively. The values of intercepts $b$ were kept $(0.0054$ and 0.7245$)$ for the breakthrough and exhaustion times, respectively. In the case of laterite, the calculated values of $a$ were 0.1344 and 0.0716 for flow rates of 5.6 and $10.5 \mathrm{~mL} / \mathrm{min}$, respectively, at the breakthrough times. At the exhaustion times, values of 1.78 and 0.9238 , respectively, were obtained for the same flow rates. From these values of $a$ and $b$, the breakthrough and exhaustion times for a $2.5 \mathrm{~cm}$ column were calculated and are shown in Table 5 .

It may be the case that the data collected for one influent solute concentration can be adjusted by the BDST technique and used to design systems for treating other influent solute concentrations. If a laboratory test is conducted at solute concentration $C_{1}$ under an equation of the form:

$$
t=a_{1} x+b_{1}
$$

...where $\mathrm{t}$ is possible to predict the equation for concentration $C_{2}$ as:

$$
\begin{gathered}
a_{2}=a_{1} \frac{C_{1}}{C_{2}} \\
b_{2}=b_{1}\left(\frac{C_{1}}{C_{2}}\right) \frac{\ln \left(C_{2} / C_{F}-1\right)}{\ln \left(C_{1} / C_{B}-1\right)}
\end{gathered}
$$

...where $a_{1}=$ the slope at concentration $C_{1} ; a_{2}=$ the slope at concentration $C_{2} ; b_{1}=$ the intercept at concentration $C_{1} ; b_{2}=$ the intercept at concentration $C_{2}$; $C_{\mathrm{F}}=$ the effluent concentration at influent concentration $C_{2}$; and $C_{\mathrm{B}}=$ the effluent concentration at influent concentration $C_{1}$.

For an influent concentration of $1.45 \mathrm{mg} / \mathrm{L}$, the values of $a_{2}$ and $b_{2}$, calculated from Eqs. (12) and (13) at the breakthrough points, were 0.0215 and -0.0015 , respectively, for GFH, while the use of laterite produced 0.025 and -0.0107 , respectively. At the exhaustion times, the results for the $a$ and $b$ values were 0.286 and 0.2 for $\mathrm{GFH}$, but using laterite, values of 0.334 and -0.12 were obtained. The same calculations were performed for a smaller influent concentration of $0.237 \mathrm{mg} / \mathrm{L}$. The results are shown in Table 5.

Table 5. Comparison of theoretical service times with experimental times.

\begin{tabular}{|c|c|c|c|c|c|}
\hline \multirow{3}{*}{ Adsorbent } & \multirow{2}{*}{ Parameters } & \multicolumn{2}{|c|}{ Breakthrough time (h) } & \multicolumn{2}{|c|}{ Exhaustion time (h) } \\
\cline { 2 - 6 } & & Experimental & Theoretical & Experimental & Theoretical \\
\hline \multirow{3}{*}{ GFH } & $5.4 \mathrm{~mL} / \mathrm{min}$ & 0.33 & 0.34 & 4 & 4.36 \\
\cline { 2 - 6 } & $12.2 \mathrm{~mL} / \mathrm{min}$ & 0.08 & 0.15 & 3 & 2.78 \\
\cline { 2 - 6 } & $0.237 \mathrm{mg} / \mathrm{L}$ & 0.33 & 0.32 & 3.33 & 4 \\
\cline { 2 - 6 } & $1.45 \mathrm{mg} / \mathrm{L}$ & 0.03 & 0.05 & 2.33 & 2.92 \\
\hline \multirow{3}{*}{ Laterite } & $5.6 \mathrm{~mL} / \mathrm{min}$ & 0.25 & 0.12 & 1.25 & 1.7 \\
\cline { 2 - 6 } & $10.5 \mathrm{~mL} / \mathrm{min}$ & 0.13 & 0.24 & 3.33 & 3.68 \\
\cline { 2 - 6 } & $0.237 \mathrm{mg} / \mathrm{L}$ & 0.25 & 0.04 & 0.83 & 0.62 \\
\hline
\end{tabular}




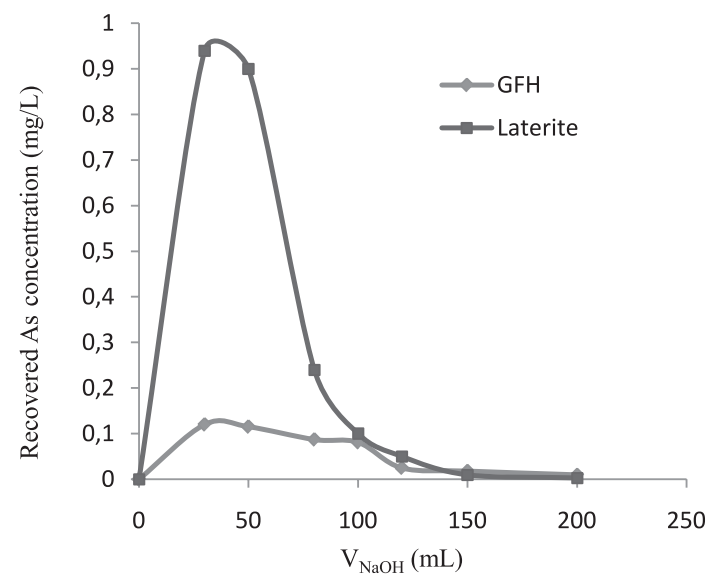

Fig. 7. Arsenic recovery profile during the regeneration of GFH and laterite.

The data reported in Table 5 indicate that the theoretical and experimental values were comparable at breakthrough. However, the time lag observed between the experimental and theoretical values at the exhaustion time could have resulted from the porosity and density of the adsorbent particles with the contribution of the number of sorption sites to the adsorbent surface. This approach indicates the possibility of predicting the column service times before the experiments were conducted.

\section{Regeneration}

For the sorption process to be viable, an efficient regeneration of the worn-out adsorbent is necessary. To achieve this, $15 \mathrm{~g}$ of exhausted material (GFH or laterite) with $0.45 \mathrm{mg}$ of arsenic fixed on GFH or laterite was regenerated using $1 \mathrm{NaOH}$ solution and a $3 \mathrm{~mL} / \mathrm{min}$ flow rate. The arsenic recovery profiles during arsenic desorption are shown in Fig. 7. The high regeneration profile for laterite compared to that for $\mathrm{GFH}$ indicates that laterite is easier to regenerate than $\mathrm{GFH}$, which has low regeneration values $[13,27]$. The calculations revealed that using laterite, $150 \mathrm{~mL}$ of $1 \mathrm{M} \mathrm{NaOH}$ solutions were adequate for about $99 \%$ arsenic recovery. It was also observed that the treatment of the exhausted bed with $100 \mathrm{~mL}$ of the $\mathrm{NaOH}$ solution could account for $\sim 97 \%$ of the arsenic recovery. Conversely, with $150 \mathrm{~mL}$ of the $\mathrm{NaOH}$, only about $20 \%$ of arsenic was recovered on the worn-out GFH. From these observations, it could be inferred that the sorption sites of laterite particles are easily accessible through the interparticle pore network.

\section{Conclusions}

The Lamdong laterite and GFH were found to be effective adsorbents for the removal of arsenic from the groundwater. The adsorption capacity of laterite at $9.7 \mathrm{~mL} / \mathrm{min}$ was similar to that of $\mathrm{GFH}(0.02 \mathrm{mg} / \mathrm{g})$ at $11.2 \mathrm{~mL} / \mathrm{min}$. However, the increase of the flow rate to $11.2 \mathrm{~mL} / \mathrm{min}$ using laterite showed a lower capacity $(0.6 \mathrm{mg} / \mathrm{L})$. It was noticed that the breakthrough time decreased with the increase in both the flow rate and the initial arsenic concentration. The increase of the $\mathrm{pH}$ value resulted in a decrease in the percentage of arsenic removal, while the $\mathrm{pH}$ value increased with an increase of the initial arsenic concentration. The modeling of experimental data using the BDST approach produced results in agreement with the experimental breakthrough times, but a time lag was observed with the exhaustion times. The arsenic speciation in the groundwater indicated the presence of $\mathrm{As}(\mathrm{V}), \mathrm{As}(\mathrm{III})$ and the particulate form with a predominance of $\mathrm{As}(\mathrm{V})$ in the dissolved form of arsenic. The presence of competing anions, such as phosphates, sulfates, and bicarbonates in the well water affects the capacity of laterite. An aqueous $1 \mathrm{M} \mathrm{NaOH}$ solution could regenerate more laterite (99\%), compared to the GFH material (20\%) after adsorption.

\section{Acknowledgements}

The authors are thankful to the Federal Ministry for Economic Cooperation and Development - Germany (BMZ), German Academic Exchange Service (DAAD), Excellence Centre for Development Cooperation, Sustainable Water Management (EXCEED/ SWINDON) and Technical University of Braunschweig (TUBS) for their financial and technical support. We also owe special thanks to Dr. Samuel Paré from Laboratoire de Chimie Analytique, Environnementaleet Bio-Organique, UFR-SEA, Université de Ouagadougou, Prof. Phuoc Van Nguyen from Vietnam National University - Ho Chi Minh City, and Dr. Tap Huu Van from Thai Nguyen University, who have offered many valuable suggestions at various states of this manuscript.

\section{Conflict of Interest}

The authors declare no conflict of interest.

\section{References}

1. LUU T.L. Remarks on the current quality of groundwater in Vietnam. Environ. Sci. Pollut. Res. Int., 26 (2), 1163, 2019.

2. SHANKAR S., SHANKER U. Arsenic contamination of groundwater: a review of sources, prevalence, health risks, and strategies for mitigation. Sci. World J., 340524,1, 2014.

3. SERT S., CELIK A., TIRTOM V.N. Removal of arsenic (III) ions from aqueous solutions by modified hazelnut shell. Desalin. Water Treat., 75,115, 2017.

4. JIANG J.Q., ASHEKUZZAMAN S.M., JIANG A., SHARIFUZZAMAN S.M., CHOWDHURY S.R. Arsenic contaminated groundwater and its treatment options in Bangladesh. Int. J. Environ. Res. Public Health, 10 (1), 18, 2012. 
5. SATYAPAL G.K., MISHRA S.K., SRIVASTAVA A., RANJAN R.K., PRAKASH K., HAQUE R., KUMAR N. Possible bioremediation of arsenic toxicity by isolating indigenous bacteria from the middle Gangetic plain of Bihar, India. Biotechnol. Rep., 17, 117, 2018.

6. WINKEL L.H.E., TRANG P.T.K., LAN V.M., STENGEL C., AMINI M., HA N.T., VIET P.H., BERG M. Arsenic pollution of groundwater in Vietnam exacerbated by deep aquifer exploitation for more than a century. Proc. Natl. Acad. Sci., 108 (4), 1246, 2011.

7. SOMÉ I., SAKIRA A., OUÉDRAOGO M., OUÉDRAOGO T., TRAORÉ A., SONDO B., GUISSOU P. Arsenic levels in tube-wells water, food, residents' urine and the prevalence of skin lesions in Yatenga province, Burkina Faso. Interdiscip. Toxicol., 5 (1), 38, 2012.

8. NICOMEL N., LEUS K., FOLENS K., VAN DER VOORT P., DU LAING G. Technologies for arsenic removal from water: current status and future perspectives. Int. J. Environ. Res. Public Health, 13 (1), 62, 2016.

9. TUNA A.Ö.A., ÖZDEMIR E., ŞIMŞEK E.B., BEKER U. Removal of As (V) from aqueous solution by activated carbon-based hybrid adsorbents: Impact of experimental conditions. Chem. Eng. J., 223,116, 2013.

10. CHIBAN M., ZERBET M., CARJA G., SINAN F. Application of low-cost adsorbents for arsenic removal: A review. J. Environ. Chem. Ecotoxicol., 4 (5), 91, 2012.

11. TE B., WICHITSATHIAN B., YOSSAPOL C., WONGLERTARAK W. Investigation of Arsenic Removal from Water by Iron-Mixed Mesoporous Pellet in a Continuous Fixed-Bed Column. Water, Air, Soil Pollut., 229 (9), 296, 2018

12. PERSONS B.S. Laterite: genesis, location, use., Springer; 156, USA, 2012

13. PHAM T.D., NGUYEN H.H., NGUYEN N.V., VU T.T., PHAM T.N.M., DOAN T.H.Y., NGUYEN M.H., NGO T.M.V. Adsorptive removal of copper by using surfactant modified laterite soil. J. Chem., 1986071, 1, 2017.

14. ROY P., MONDAL N.K., BHATTACHARYA S., DAS B., DAS K. Removal of arsenic (III) and arsenic (V) on chemically modified low-cost adsorbent: batch and column operations. Appl. Water Sci., 3 (1), 293, 2013.

15. MAJI S.K., PAL A., PAL T. Arsenic removal from reallife groundwater by adsorption on laterite soil. J. Hazard. Mater., 151 (2), 811, 2008
16. SANOU Y., PARE S., PHUONG N.T.T., PHUOC N.V. Experimental and kinetic modelling of As (V) adsorption on granular ferric hydroxide and laterite. J. Env. Treat. Tech., 4 (3), 62, 2016.

17. RICE E.W., BAIRD R.B., EATON A.D., CLESCERI L.S. Standard methods for the examination of water and wastewater, $23^{\text {rd }}$., American Public Health Association;2200,USA, 2017.

18. THIRUNAVUKKARASU O.S., VIRARAGHAVAN T., SUBRAMANIAN K.S. Removal of arsenic in drinking water by iron oxide-coated sand and ferrihydrite-batch studies. Water Qual. Res. J. Can., 36 (1), 55, 2001.

19. BOHART G.S., ADAMS E.Q. Some aspects of the behavior of charcoal with respect to chlorine. J. Am. Chem. Soc., 42 (3), 523, 1920.

20. KUNDU S., GUPTA A.K. Analysis and modeling of fixed bed column operations on As (V) removal by adsorption onto iron oxide-coated cement (IOCC). J. Colloid Interface Sci., 290 (1), 52, 2005.

21. MAJI S.K., PAL A., PAL T., ADAK A. Modeling and fixed bed column adsorption of As (V) on laterite soil. Journal of Environmental Science and Health Part A, 42 (11), 1585, 2007.

22. HUTCHINS R.A. New method simplifies design of activated carbon systems. Chem. Eng., 80 (19), 133, 1973.

23. MEROLA R.B., HIEN T.T., QUYEN D.T.T., VENGOSH A. Arsenic exposure to drinking water in the Mekong Delta. Sci. Total Environ., 511,544, 2015.

24. OUÉDRAOGO I.W.K., PEHLIVAN E., TRAN H.T., BONZI-COULIBALY Y.L., ZACHMANN D., BAHADIR M. Synthesis of iron oxyhydroxide-coated rice straw (IOC$\mathrm{RS})$ and its application in arsenic (V) removal from water. J. Water. Heal., 13 (3), 726, 2015.

25. MAITI A., DASGUPTA S., BASU J.K., DE S. Adsorption of arsenite using natural laterite as adsorbent. Sep. Purif. Technol., 55 (3), 350, 2007.

26. MAITI A., BASU J.K., DE S. Experimental and kinetic modeling of As (V) and As (III) adsorption on treated laterite using synthetic and contaminated groundwater: effects of phosphate, silicate and carbonate ions. Chem. Eng. J., 191,1, 2012.

27. USMAN M., KATSOYIANNIS I., MITRAKAS M., ZOUBOULIS A., ERNST M. Performance evaluation of small sized powdered ferric hydroxide as arsenic adsorbent. Water, 10 (7), 957, 2018. 